\title{
Artificial Neural Network Models to Build an Early Warning System for Turkish Commercial Banks before and after the 2001 Financial Crisis
}

\author{
Prof. Dr. Süleyman Bilgin Kılıç (Çukurova University, Turkey) \\ Assoc. Prof. Dr. Kenan Lopcu (Çukurova University, Turkey) \\ Asst. Prof. Dr. Semin Paksoy (Çukurova University, Turkey)
}

\begin{abstract}
The objective of this paper is to measure the failure risk of Turkish commercial banks. Bank failures bring to bear high costs on economies as well as on governments and eventually on the public and the taxpayers. During the past two decades, many developed and developing economies have experienced large scale bank failures, and estimates for average bank restructuring costs range from $6 \%$ to $10 \%$ of the Gross Domestic Product. In Turkey the amount of restructuring costs is approximately $30 \%$ of the Gross Domestic Product. In this study, we use 29 selected financial ratios of banks across 1996-2012 periods and the Artificial Neural Network Models to build an early warning system. If commercial bank failure were a predictable event, bank restructuring costs could be minimized. Additionally, if early warning systems are used effectively, the regulatory actions necessary to prevent banks from failing could be taken in advance or in the least a more orderly process of bank closures could be administered. The results overall indicate that almost all commercial banks currently operating in the Turkish banking sector are quite sound and far from failure.
\end{abstract}

\section{Introduction}

Bank failures bring to bear high costs on economies as well as on governments, and eventually on the public and the taxpayers. During the past two decades, many developed and developing economies in the world have experienced large scale bank failures, and the estimates for (international) average bank restructuring costs range from 6\% to $10 \%$ of Gross Domestic Product (GDP) (Hutchison and McDill, 1999). In Turkey this amount is approximately $30 \%$ of the GDP (Kılıç, 2003). Obviously, if bank failure were a predictable event, bank restructuring costs could be minimized. If early warning systems are used effectively in bank supervision, the regulatory actions necessary to prevent banks from failing can be taken in advance or a more orderly process of bank closures can be administered.

Early bank failure studies employed multivariate statistical analyses, including regression analysis. For example, Meyer and Pifer (1970), and Rose and Kolari (1985) used discriminant models; Sinkey (1975) used logit models; Cole and Gunther (1998), and Pantolone and Platt (1987) used probit models.

Recent important studies conducted toward investigating causes of great bank failures in the Unided States. Cebula, et al. (2011) investigated the factors that systematically influence bank failures, including major federal government banking statutes that are implemented over the period 1970 through 2009, with emphasis on two major banking statutes, the Federal Deposit Insurance Corporation Improvement Act of 1991 FDICIA and the RNIBA. Over the study period, their evidence strongly implies that FDICIA acted to reduce bank failures whereas Riegle-Neal Interstate Banking and Branching Efficiency Act of 1994 RNIBA (presumably by increasing competition and/or increasing costs through branch bank expansion) induced a net increase in bank failures in the U.S. Jin et al. (2011) examined the ability of selected accounting and audit quality variables measured in a period prior to the financial crisis (i.e., the four quarters of 2006), to predict banks that subsequently failed during the financial crisis. They employed two sets of samples from the US: a troubled banks sample that includes banks that failed in or after 2007 as well as banks classified as being troubled based on profitability, loan quality, and balance sheet position in 2007, and a full sample that includes all banks with available required data. Using the troubled banks sample, they identified the following ten predictors of bank failure: auditor type, Tier 1 capital ratio, proportion of securitized loans, nonperforming loans, loan loss provisions, growth in commercial loans, growth in real estate loans, growth in overall loans, loan mix, and whether the bank is a public bank. Following this study, Jin et al. (2013) studied the impact of the FDICIA on banks' risk-taking behavior prior to the recent financial crisis and the consequent implications for bank failure and financial trouble during the crisis period. The study provided evidence that banks required to comply with the FDICIA internal control requirements have lower risk taking in the pre-crisis period. Specifically, the volatility of net interest margin, the volatility of earnings, and $\mathrm{Z}$ score show less risk-taking behavior. Furthermore, these banks are less likely to experience failure and financial trouble during the crisis period. Fatima and Silvia (2013) used survival analysis to determine how early the indications of bank failure can be observed. They find that banks with high loan to asset and high personal loan to assets ratios are more likely to survive. Older banks and banks with high real estate and agricultural loans, loan loss allowance, loan charges off 
and non-performing loans to assets ratio are more likely to fail. It is possible to predict survival functions of $<50 \%$ for failed banks, 3 years or less before failure.

Some other recent important studies conducted toward investigating causes of bank failures in other countries and regions. Arena (2008) used bank-level data from recent banking crises in East Asia and Latin America to address the following two questions: (1) To what extent did individual bank conditions explain the failures? (2) In terms of their fundamentals, was it mainly the weak banks ex ante that failed in the crisis countries? The results of the study showed that for the two regions, bank-level fundamentals significantly affect the likelihood of collapse for these banks; systemic shocks (both macroeconomic and liquidity) that triggered the crises mainly destabilized the weak banks ex ante, particularly in East Asia. Brown and Dinç (2011) studied bank failures in twenty-one emerging market countries in the 1990s. By using a competing risk hazard model for bank survival, they show that a government is less likely to take over or close a failing bank if the banking system is weak. They also show that the Too-Many-to-Fail effect is stronger for larger banks and when there is a large government budget deficit. Huang et al. (2012) evaluated data from 858 international banks (including banking holding companies) from 2005 to 2008 and applies a logistic model to analyze critical factors. They showed that equity-to-assets (ETA) and interest income - interest expense/income (NIN) had negative relationships with financial distress. They stated that ETA and NIN were indicative of banking financial distress and best predicted trends in Association of Southeast Asian Nations and European Union banks. Fungáčová and Weill (2013) investigate the role of bank competition on the occurrence of bank failures by analysing a large sample of Russian banks for the period 2001-2007, as an example of an emerging market, and find that tighter bank competition enhances the occurrence of bank failures; increase bank competition could undermine financial stability.

Some studies combine the nonparametric approaches with the parametric multivariate statistical methods including discriminant or logit analysis for bank failure prediction. For example, Tam and Kiang (1992) introduce the neural network approach to perform discriminant analysis as a promising method of evaluating banking conditions. Jo and Han (1996) suggest an integrated model approach for bankruptcy prediction using discriminant analysis and two artificial intelligence models, namely, neural network and case-based forecasting, and conclude that the integrated models have higher prediction accuracy than individual models. Alam, Booth and Thordarson (2000) state that fuzzy clustering algorithm and self-organizing neural networks provide valuable information to identify potentially failing banks. Kolari et al. (2002) use both parametric logit analysis and the nonparametric trait approach to develop computer-based early warning systems to identify large bank failures, and conclude that the system provides valuable information about the future viability of large banks. Lam and Moy (2002) combine several discriminant methods and perform simulation analysis to enhance the accuracy of results for classification problems in discriminant analysis. Zhao et al. (2009) empirically compared the performance of two sets of classifiers for bank failure prediction; one built using raw accounting variables and the other built using constructed financial ratios. They used four popular data mining methods to learn the classifiers: logistic regression, decision tree, neural network, and k-nearest neighbor. The results of the study indicated that feature construction, guided by domain knowledge, significantly improves classifier performance and that the degree of improvement varies significantly across the methods. Chauhan et al. (2009) were proposed differential evolution algorithm (DE) to train a wavelet neural network (WNN). They named resulting network as differential evolution trained wavelet neural network (DEWNN) and tested the efficacy of DEWNN on bankruptcy prediction datasets of US banks, Turkish banks and Spanish banks. By employing 10-fold cross validation method, they concluded that DEWNN outperformed the original WNN in terms of accuracy and sensitivity across all problems.

Kılıç (2003), and Canbaş et al. (2005) combined Principal Component analysis (PCA) with discriminant, logit and probit models to develop an Integrated Early Warning System for predicting bank failure one year in advance in the Turkish banking sector. More recently, Shin and Kılıç (2006) used PCA-based neural network committee model for early warning of bank failure and also, Shin et al. (2006) used ensemble prediction of bank failure through diversification of input features. Lopcu and Kılıç (2012) used PCA and the logit model to build and early warning system to predict the out of sample failure probabilities of the Turkish commercial banks. Boyacioglu et al. (2009) aimed to apply various neural network techniques, support vector machines and multivariate statistical methods to the bank failure prediction in Turkey. Twenty financial ratios with six feature groups including capital adequacy, asset quality, management quality, earnings, liquidity and sensitivity to market risk (CAMELS) are selected as predictor variables in the study. In the category of neural networks, they employed four different architectures namely multi-layer perceptron, competitive learning, self-organizing map and learning vector quantization. In the category of multivariate statistical methods; they tested multivariate discriminant analysis, k-means cluster analysis and logistic regression analysis. Results of the study showed that multi-layer perceptron and learning vector quantization can be considered as the most successful models in predicting the financial failure of banks. Penas, and Tümer (2010) explored whether Turkish banks with worsening indicators of financial fragility were subject to market monitoring during the years leading to the 2000/2001 crisis, and how the quality and timeliness of the disclosure affect market reaction. They found that 
shareholders reacted negatively to indicators of financial fragility and suggested that securities prices react to financial fragility indicators should not be taken as sufficient evidence of banks' safety and soundness. Erdal and Ekinci (2013) presented a comparison of three different artificial intelligence methods, namely support vector machines (SVMs), radial basis function neural network (RBF-NN) and multilayer perceptions (MLPs); in addition to subjecting the explanatory variables to principal component analysis (PCA). The extent of this study encompasses 37 privately owned commercial banks (17 failed, 20 non-failed) that were operating in Turkey for the period of 1997-2001. They concluded that, (i) PCA does not appear to be an effective method with respect to the improvement of predictive power; (ii) SVMs and RBF demonstrated similar levels of predictive power; albeit SVMs was found to be the best model in terms of total predictive power; (iii) MLPs method stood out among the SVMs and RBF methods in a negative sense and exhibits the lowest predictive power.

In this current study, as a follow up to the study by Canbaş et al.(2005) and Lopcu and Kılıç (2012), an expanded data set of commercial banks are pooled and Artificial Neural Network (ANN) Models developed to build an early warning system for 1996-2000 and 2002-1012 periods to predict bank failures as many as 7 years in advance. In particular, representing the banks by a dummy dependent variable $y_{b t}$, we assign the value of 1 from 1996 on, for the banks that have failed in year $t$, and exclude them from the analysis after the year failure has been announced.

Bank failures can be considered as a continuous process in time, although failure is recorded at a specific point in time. We maintain that failure is mainly due to continuously worsening financial conditions attributable to a bank's misguided internal management policies over a number of years. Financial ratios provide valuable quantitative information about changes in financial conditions of banks. Decision makers should examine banks over time to capture information about the progress towards the failure.

The major contribution of this study to the literature is the use of information provided by financial ratios that differ significantly in means between the failed and non-failed group of banks and comparison of Turkish commercial banks' performance before and after 2001 financial crises. 2001 was the year of financial and economic crises in Turkey. Starting on February 21, 2001 Turkish lira lost it value sharply, interest rates skyrocketed, and inflation started to soar. The Turkish GDP was also reduced significantly in the same year. As part of a larger economic reform package following the crisis, banking sector as well was reorganized. It is worth noting that of the 22 failed banks included in our data set 14 failed during the period between the recent months of 2000 and July 2003 (Table 3).

\begin{tabular}{|c|c|c|c|}
\hline Code & Ratio Categories and Names & Code & Ratio Categories and Names \\
\hline & Assets Quality, \% & & Share in Group, \% \\
\hline R1 & Total Loans/Total Assets & R17 & Total Assets \\
\hline R2 & Non Performing Loans/Total Loans & R18 & Total Loans \\
\hline \multirow[t]{2}{*}{ R3 } & Permanent Assets/Total Assets & R19 & Total Deposits \\
\hline & Liquidity, \% & & Branch Ratios, Million TRY \\
\hline $\mathrm{R} 4$ & Liquid Assets/Total Assets & $\mathrm{R} 20$ & Total Assets / No. of Branches \\
\hline R5 & Liquid Assets/(Deposits + Non-deposit Funds) & R21 & Total Deposits / No. of Branches \\
\hline \multirow[t]{2}{*}{ R6 } & Fx Liquid Assets/Fx Liabilities & R22 & TL Deposits / No. of Branches \\
\hline & Profitability, \% & $\mathrm{R} 23$ & Fx Deposits / No. of Branches \\
\hline R7 & Net Income(Loss)/Average T. Assets & R24 & No. of Personnel / No. of Branches \\
\hline R8 & Net Income(Loss)/Shareholder's Equity & $\mathrm{R} 25$ & Total Loans / No. of Branches \\
\hline \multirow[t]{2}{*}{ R9 } & Income Before Tax / Average Total Assets & R26 & Net Income / No. of Branches \\
\hline & Income-Expenditure Structure, $\%$ & & Activity Ratios \\
\hline R10 & Interest Income/Total Expense & R27 & $\begin{array}{l}\text { (Salary and Emp'ee Bene.+Res. for } \\
\text { Retire.)/No.of Pers.(Billion TL) }\end{array}$ \\
\hline R11 & Interest Income/Interest Expenses & $\mathrm{R} 28$ & $\begin{array}{l}\text { Reserve for Seniority Pay/No.of } \\
\text { Personnel (Billion TL) }\end{array}$ \\
\hline R12 & Non-Interest Income/Non-Interest Expenses & R29 & $\begin{array}{l}\text { (Salaries and Emp'ee Benefits+Reserve } \\
\text { for Retirement)/T.Assets }\end{array}$ \\
\hline \multirow[t]{2}{*}{$\mathrm{R} 13$} & Total Income/Total Expenditure & & \\
\hline & Share in Sector, \% & & \\
\hline R14 & Total Assets & & \\
\hline R15 & Total Loans & & \\
\hline R16 & Total Deposits & & \\
\hline
\end{tabular}

Table 1. Financial ratios used in the study

In this study, we use 29 financial ratios published by the Banks Association of Turkey (BAT) and given in Table 1 to build ANN models for the pre and post 2001 periods to predict the bank failures in advance. We test 
the mean equivalence of the ratios for failed and non-failed banks via ANOVA tests, and use only the financial ratios, which has significantly different means as inputs in the ANN models. The use of significantly different financial ratios provides more refined and enhanced information to the decision makers than the direct use of all available financial ratios.

The rest of this article is organized as follows: Section 2 reports the methodology and results, including the sample and variable selection; the determination of significant financial ratios; and the estimation and interpretation of the results from the ANN models. Then, section 3 concludes the article.

\section{Data Methodology and Results}

\subsection{Data, Sample and Variable Selection}

The sample set covers all commercial banks in the Turkish banking sector for the period of 1996-20012. The number of banks in the sector changes from year to year because of mergers, buyouts and failures. The maximum number included in the analysis is 46 for 1997(Table 3), including 22 banks that had failed between 1997 and 2003. Currently 26 commercial banks operate in the Turkish banking sector (Table 4). In 1999 and 2000 the BAT published 49 financial ratios annually for each bank operated in the Turkish banking sector, including the banks whose failure had been announced and eventually transferred to the Savings Deposits Insurance Fund (SDIF). Although, the ratios published starts from 1992, many of the ratios for a number of banks are missing for the initial years and become more regular after 1996.

Starting with 2002 the BAT began to publish 66 annual ratios for each bank. The ratios before and after 2001 are not consistent in term of number of the banks operating in the industry, and the ratios published for each bank. However, 29 ratios for each bank are compatible both in the data published prior to 2001 and after 2001 (Table 1). Thus, our data set includes 29 common annual ratios and covers the period 1996 to 2012, with the exception of 2001. Of the 22 failed banks included in our data set, 14 failed during the period between the recent months of 2000 and July 2003 (Table 3).

All the branch and activity ratios in current TL are converted to 2005 TL using the revaluation index according to tax procedure laws. Though, none of these ratios turns out to be significant in the ANOVA, except net income per branch (R26). Using CPI and PPI from the OECD data base for Turkey to convert these ratios to $2005 \mathrm{TL}$ produces similar results.

Using the uni-variate analysis of variance (ANOVA), we determine the most relevant financial ratios for the bank failures. The null hypothesis in ANOVA is that the means of the failed and non-failed banks are equal for a given ratio. According to the results of the ANOVA tests, 11 ratios (R2-R9, R13, R18 and R26) out of 29 emerge as statistically significant at $1 \%$ level. These are the most relevant financial ratios that have high discriminating ability for the two groups of failed versus non-failed banks.

In order to compare the financial performance of commercial banks before and after 2001, we build an ANN model for each of the sub-periods of 1996-2000 and 2002-2012. However, data for the period of 2002-2012 include no failed banks. So, we combine the ratios of failed banks from the period of 1996-2000 with the ratios of 2002-2012 nonfailed banks to be able to build an ANN model for the post 2001 period.

\subsection{Estimation of the ANN Models}

We partition dataset for each of the ANN model we built (1996-2000 and 2002-1012 periods) into the training and testing samples by randomly assigning $70 \%$ data to the training sample and the rest (30\%) to the testing sample. The training sample data, used to train the neural network as certain percentage of observations in the dataset must be assigned to the training sample in order to build a model. The testing sample is comprised of an independent set of observations used to keep track of errors during training to prevent overtraining. Network training is generally the most efficient if the testing sample is smaller than the training sample. So, we assign circa $30 \%$ of the observations to the testing sample.

We directly use 11 significant ratios as inputs to the ANN models. The outputs of the models are actual status of the banks which is either 0 (for non-failed bank) or 1 (for failed bank). After so many experiment we trained two ANN models. The architecture of ANN model for the period of 1996-2000, which consists of 1 input layers (11 significant ratios denoted by $R_{i}, i=1,2, \ldots, 11$ ), 1 hidden layer with 7 nodes and 1 output layer with 2 nodes. The model for the period of 2002-2012 consists of 1 hidden layer again, but includes 9 hidden nodes. For the sake of conserving space we do not present the figure describing the model architecture for 2002-2012 and the parameter estimates (weights) for both ANN models.

The ANN models trained as follows;

Let $R_{i}(i=1, \ldots, 11$.) denote 11 significant financial ratios which are used as input in the input layer; $i, j$ and $k$ represent input, hidden and output layers; $n, m$ and $p$ indicate number of nodes in input, hidden and output layers respectively. Each hidden node $j$ produce an output by using following logit (sigmoid) activation function $f\left(x_{j}\right)$ which uses the weighted sum of the inputs $R_{i}$ from the input layer;

$$
f\left(x_{j}\right)=1 /\left(1+e^{-z_{j}}\right), \quad z_{j}=\sum_{i=1}^{n} w_{i j} R_{i}, j=1, \ldots, m .
$$


Here, wij is connection weights from input node $\mathrm{i}$ to hidden node $\mathrm{j}$. The outputs from the hidden layer nodes are the inputs of the output layer nodes. Also, each output node k produce an output by using following sigmoid activation function $\mathrm{f}(\mathrm{xk})$ which uses the weighted sum of the inputs $\mathrm{f}(\mathrm{xj})$ from the nodes of hidden layer;

$$
y^{\prime}=f\left(x_{k}\right)=1 /\left(1+e^{-z_{k}}\right), \quad z_{k}=\sum_{j=1}^{m} w_{j k} f\left(x_{j}\right), k=1, \ldots, p \text {. }
$$

Here, $y^{\prime}$ denotes predicted value of the ANN model $\left(0 \leq y^{\prime} \leq 1\right)$, wjk is connection weights from hidden node $j$ to output node $\mathrm{k}$. Hence, the prediction error $\left(\varepsilon t=y t-y^{\prime} t\right)$ is the difference between the actual status $(y t)$ which is either 0 (for non-failed bank) or 1 (for failed bank), and predicted failure probability value ( $y_{t}^{\prime}$ ) for bank $t$.

Hence, the total prediction error function of ANN given the training sample size of $N$ is;

$$
S(w)=\sum_{t=1}^{N} \varepsilon_{t}
$$

Values of the all weights $\left(w_{i j}, w_{j k}\right)$ in the ANN model were determined by the following estimation algorithm:

All weights were assigned with random values initially and modified by the gradient descent algorithm according to the gradient vector of the total prediction error function;

$$
w_{\text {new }}=w_{\text {old }}+\left.\alpha \nabla E(w)\right|_{w_{\text {old }}}, \nabla E(w)=(\partial S(w) / \partial w)
$$

Here, $\alpha$ is the learning parameter $(0 \leq \alpha \leq 1)$, and taken as $\alpha=0.0001$ in this study. Iterations eventually terminated at a local minimum of the total prediction error function when $w_{\text {new }} \cong w_{\text {old }}$.

\subsection{Results}

We present the summary of the classification results for the ANN models in Tables 2. Given the limitations in data, such as starting with a limited number of ratios and not including 2001 in the analysis when 9 of the failures were announced, and assigning $y_{b t}$ the value of 1 not only in year $t$ when the failure was announced but

\begin{tabular}{|c|c|c|c|c|c|c|c|c|c|}
\hline \multicolumn{5}{|c|}{ Classification results: $1996-2000$} & \multicolumn{5}{|c|}{ Classification results: $2002-2012$} \\
\hline \multicolumn{2}{|c|}{ 1996-2000 } & \multicolumn{3}{|c|}{ Predicted } & & & \multicolumn{3}{|c|}{ Predicted } \\
\hline Training & Observed & $\mathbf{0}$ & 1 & \% Correct & Training & Observed & $\mathbf{0}$ & 1 & \% Correct \\
\hline & 0 & 76 & 4 & 95,0 & & 0 & 180 & 1 & 99,4 \\
\hline & 1 & 12 & 60 & 83,3 & & 1 & 0 & 73 & 100,0 \\
\hline \multicolumn{2}{|c|}{ Training Percentage } & 57,9 & 42,1 & 89,5 & \multicolumn{2}{|c|}{ Training Percentage } & 70,9 & 29,1 & 99,6 \\
\hline \multirow[t]{2}{*}{ Testing } & 0 & 33 & 5 & 86,8 & Testing & 0 & 92 & 0 & 100,0 \\
\hline & 1 & 3 & 24 & 88,9 & & 1 & 2 & 24 & 92,3 \\
\hline \multicolumn{2}{|c|}{ Testing Percentage } & 55,4 & 44,6 & 87,7 & \multicolumn{2}{|c|}{ Testing Percentage } & 79,7 & 20,3 & 98,3 \\
\hline
\end{tabular}
as many as 7 years in advance, we interpret these results as the models having a very high predictive power, especially for the 2002-2012 period.

Table 2. Classification results

In particular, 60 of 72 failures in the training sample and 24 of 27 failures in the testing sample are predicted accurately for the 1996-2000 period. For the 2002-2012 period on the other hand, all the non-fail and fail cases are predicted accurately with $99.6 \%$ and $98.3 \%$ for the training and testing samples respectively. It can argued that predicting failures accurately is more important because, as stated previously, the international average for bank failure costs was estimated to be 6 to $10 \%$ of GDP, prior to the recent global turmoil in the financial markets started in 2008. If a bank failure is predicted in advance, the cost of the failure can at least be minimized, even if it cannot be completely eliminated.

Tables 3 and 4 present the estimated failure probabilities for each bank and the year in the sample. Overall the performance of the Turkish commercial banks appears to be much better in the post 2001 period and they are far from the risk of failure. The last row in Table 3 and the last row of the lower panel in Table 4 give the average of predicted failure probabilities for the periods before and after 2001, accordingly. In particular, the highest average failure probability in the post 2001 period is in 2002, immediately following the financial and economic crisis in Turkey and is equal to $10 \%$. However, even this high of a failure probability is lower than the smallest average failure probability of non-failed banks of 11.8\% in1998-1999 in the pre 2001 period. Starting with 2003, the average failure probabilities decline sharply followed by a slight increase $(4.5 \%)$ in the wave of global financial crisis in 2007 and become nearly zero in 2009, 2011 and 2012. 


\begin{tabular}{|c|c|c|c|c|c|c|c|}
\hline Bank & Failure & 1996 & 1997 & 1998 & 1999 & 2000 & Average \\
\hline Adabank A.Ş. & & 0,484 & 0,398 & 0,278 & 0,357 & 0,031 & 0,309 \\
\hline Akbank T.A.Ş. & & 0,015 & 0,002 & 0,004 & 0,033 & 0,049 & 0,021 \\
\hline Alternatif Bank A.Ş. & & 0,052 & $0,623 *$ & $0,708^{*}$ & 0,017 & 0,487 & 0,378 \\
\hline Anadolubank & & NA & 0,020 & 0,046 & 0,313 & 0,445 & 0,206 \\
\hline Arap Türk Ba & & 0,040 & 0,093 & 0,046 & 0,078 & 0,055 & 0,062 \\
\hline Denizbank A. & & NA & 0,024 & 0,087 & 0,048 & $0,563^{*}$ & 0,181 \\
\hline Fiba Bank A.Ş. & & 0,063 & 0,023 & 0,036 & 0,254 & 0,203 & 0,116 \\
\hline Finans Bank A.Ş. & & 0,154 & 0,158 & 0,106 & 0,049 & 0,069 & 0,108 \\
\hline HSBC Bank A.Ş. & & 0,154 & 0,223 & 0,183 & 0,052 & 0,103 & 0,143 \\
\hline Koçbank A.Ş. & & 0,049 & 0,205 & 0,235 & 0,034 & $0,570 *$ & 0,218 \\
\hline MNG Bank A.Ş. & & 0,559* & 0,021 & 0,028 & 0,282 & $0,937 *$ & 0,365 \\
\hline Osmanlı Bankası A.Ş. & & 0,013 & 0,033 & 0,006 & 0,007 & 0,014 & 0,015 \\
\hline Oyak Bank A.Ş. & & 0,000 & 0,033 & 0,003 & 0,020 & 0,963* & 0,204 \\
\hline Şekerbank T.A.Ş. & & 0,148 & 0,414 & 0,359 & 0,287 & 0,429 & $\mathbf{0 , 3 2 7}$ \\
\hline Tekstil Bankası A.Ş. & & 0,282 & 0,311 & 0,092 & 0,225 & 0,468 & 0,276 \\
\hline Türk Dış Ticaret Bankası A.Ş. & & 0,186 & $0,540 *$ & 0,070 & 0,162 & 0,123 & 0,216 \\
\hline Türk Ekonomi Bankası A.Ş. & & 0,410 & 0,413 & 0,120 & 0,356 & 0,465 & $\mathbf{0 , 3 5 3}$ \\
\hline Turkish Bank A.Ş. & & $0,760 *$ & 0,196 & 0,056 & 0,043 & 0,044 & $\mathbf{0 , 2 2 0}$ \\
\hline T.C. Ziraat Bankası & & 0,002 & 0,064 & 0,025 & 0,052 & 0,020 & $\mathbf{0 , 0 3 3}$ \\
\hline Türkiye Garanti Bankası A.Ş. & & 0,010 & 0,004 & 0,013 & 0,010 & 0,008 & 0,009 \\
\hline Türkiye Halk Bankası A.Ş. & & 0,027 & 0,049 & 0,125 & 0,132 & 0,227 & 0,112 \\
\hline Türkiye İş Bankası A.Ş. & & 0,001 & 0,001 & 0,001 & 0,001 & 0,003 & 0,001 \\
\hline Türkiye Vakıflar Bank. T.A.O. & & 0,013 & 0,000 & 0,001 & 0,008 & 0,170 & $\mathbf{0 , 0 3 8}$ \\
\hline Yapı ve Kredi Bankası A.Ş. & & 0,093 & 0,023 & 0,205 & 0,003 & 0,002 & 0,065 \\
\hline Bank Ekspres & Dec. 1998 & 0,716 & $0,387 *$ & 0,999 & NA & NA & $\mathbf{0 , 7 0 1}$ \\
\hline Bank Kapital & Oct. 2000 & $0,065 *$ & 0,311* & 0,679 & 0,990 & 1,000 & 0,609 \\
\hline Bayındırbank & July 2001 & 0,840 & 0,998 & 0,740 & 0,641 & 0,632 & $\mathbf{0 , 7 7 0}$ \\
\hline Demirbank T. & Dec. 2000 & 0,599 & 0,578 & $0,337 *$ & $0,189 *$ & 0,998 & 0,540 \\
\hline Ege Giyim Sa & July 2001 & 0,937 & 0,956 & 0,995 & 0,959 & 0,997 & 0,969 \\
\hline Egebank A.Ş. & Dec. 1999 & 0,959 & 0,821 & 0,795 & 0,994 & NA & $\mathbf{0 , 8 9 2}$ \\
\hline Eskişehir Ba & Dec. 1999 & 0,940 & 0,931 & 0,994 & 0,991 & NA & 0,964 \\
\hline Etibank A.Ş. & Oct. 2000 & $0,348 *$ & 0,885 & 0,860 & 0,559 & 0,952 & 0,721 \\
\hline İktisat Bank & March 2001 & $0,283 *$ & $0,224 *$ & 0,705 & 0,754 & 0,997 & 0,592 \\
\hline Interbank & Jan. 1999 & 0,998 & 0,999 & 0,999 & 1,000 & NA & 0,999 \\
\hline Kentbank A.Ş & July 2001 & 0,727 & 0,537 & 0,894 & 0,815 & 0,824 & 0,759 \\
\hline Milli Aydın & July 2001 & 0,991 & 0,992 & 0,999 & 0,997 & 0,997 & 0,995 \\
\hline Pamukbank T. & June 2002 & 0,982 & 0,973 & 0,955 & 0,846 & 0,820 & 0,915 \\
\hline Sitebank A.Ş. & July 2001 & 0,656 & $0,416 *$ & 0,513 & 0,930 & 0,988 & $\mathbf{0 , 7 0 1}$ \\
\hline Sümerbank A.Ş. & Dec 1999 & 0,564 & 0,526 & 0,912 & 1,000 & $\mathrm{NA}$ & 0,751 \\
\hline Toprakbank A.Ș. & Nov. 2001 & 0,312* & $0,446 *$ & $0,352 *$ & $0,477 *$ & 0,495* & 0,417 \\
\hline Türk Ticaret Bankası A.Ş. & Nov. 1997 & 0,797 & 1,000 & NA & NA & NA & $\mathbf{0 , 8 9 9}$ \\
\hline Türkiye Emlak Bankası A.Ş. & July 2001 & 0,541 & 0,871 & 0,891 & 0,665 & 0,990 & $\mathbf{0 , 7 9 2}$ \\
\hline Türkiye İmar Bankası T.A.Ş. & July 2003 & 0,997 & 0,973 & 0,996 & 0,999 & 0,998 & 0,993 \\
\hline T. T.B. Yaşarbank A.Ş. & Dec. 1999 & 0,995 & 0,993 & 0,996 & 0,999 & NA & 0,996 \\
\hline Ulusal Bank T.A.Ş. & Feb. 2001 & 0,912 & 0,747 & 0,515 & 0,226* & 0,994 & 0,679 \\
\hline Yurt Ticaret ve Kredi Bankası A.Ş. & Dec. 1999 & 0,907 & 0,998 & 0,580 & 1,000 & NA & $\mathbf{0 , 8 7 1}$ \\
\hline Average & & 0,445 & 0,444 & 0,434 & 0,428 & 0,503 & $\mathbf{0 , 4 5 8}$ \\
\hline Average fail & & 0,730 & 0,753 & 0,796 & 0,802 & 0,906 & $\mathbf{0 , 7 9 3}$ \\
\hline Average non-fail & & 0,160 & 0,161 & 0,118 & 0,118 & 0,269 & 0,166 \\
\hline
\end{tabular}

Table 3. Estimated failure probabilities for 1996-2000 


\begin{tabular}{|c|c|c|c|c|c|c|}
\hline Bank & 2002 & 2003 & 2004 & 2005 & 2006 & 2007 \\
\hline T.C. Ziraat Bankası A.Ș. & 0,034 & 0,000 & 0,000 & 0,000 & 0,005 & 0,009 \\
\hline Türkiye Halk Bankası A.Ş. & 0,091 & 0,001 & 0,000 & 0,001 & 0,001 & 0,002 \\
\hline T. Vakıflar Bankası T.A.O. & 0,304 & 0,062 & 0,021 & 0,003 & 0,005 & 0,001 \\
\hline Adabank A.Ş. & 0,000 & 0,000 & 0,000 & 0,000 & 0,000 & 0,000 \\
\hline Akbank T.A.Ș. & 0,001 & 0,001 & 0,000 & 0,000 & 0,000 & 0,000 \\
\hline Alternatif Bank A.Ș. & 0,313 & 0,007 & 0,000 & 0,000 & 0,000 & 0,000 \\
\hline Anadolubank A.Ş. & 0,008 & 0,002 & 0,005 & 0,010 & 0,000 & 0,000 \\
\hline Şekerbank T.A.Ş. & 0,044 & 0,003 & 0,005 & 0,000 & 0,000 & 0,001 \\
\hline Tekstil Bankası A.Ş. & 0,352 & 0,001 & 0,000 & 0,000 & 0,001 & 0,000 \\
\hline Turkish Bank A.Ş. & 0,000 & 0,000 & 0,000 & 0,088 & 0,003 & 0,078 \\
\hline Türk Ekonomi Bankası A.Ş. & 0,000 & 0,001 & 0,000 & 0,002 & 0,003 & 0,020 \\
\hline Türkiye Garanti Bankası A.Ş. & 0,010 & 0,005 & 0,000 & 0,001 & 0,000 & 0,000 \\
\hline Türkiye İş Bankası A.Ş. & 0,156 & 0,000 & 0,000 & 0,025 & 0,052 & 0,027 \\
\hline Yapı ve Kredi Bankası A.Ș. & 0,000 & 0,144 & 0,334 & 0,034 & 0,083 & 0,249 \\
\hline Arap Türk Bankası A.Ş. & 0,001 & 0,000 & 0,000 & 0,015 & 0,001 & 0,441 \\
\hline Citibank A.Ş. & 0,000 & 0,136 & 0,000 & 0,007 & 0,000 & 0,028 \\
\hline Denizbank A.Ş. & 0,000 & 0,000 & 0,001 & 0,002 & 0,002 & 0,000 \\
\hline Deutsche Bank A.Ş. & 0,037 & 0,019 & 0,000 & 0,013 & 0,000 & 0,053 \\
\hline Burgan Bank A.Ş. $^{+}$ & 0,164 & 0,015 & 0,003 & 0,418 & 0,003 & 0,006 \\
\hline Finans Bank A.Ş. & 0,002 & 0,001 & 0,000 & 0,002 & 0,011 & 0,000 \\
\hline Fortis Bank A.Ş. & 0,000 & 0,001 & 0,000 & 0,005 & 0,007 & 0,011 \\
\hline HSBC Bank A.Ş. & 0,004 & 0,081 & 0,000 & 0,001 & 0,000 & 0,000 \\
\hline ING Bank A.Ş. & 0,783* & 0,009 & 0,001 & 0,007 & 0,019 & 0,013 \\
\hline Fiba Bank A.Ş..+ & 0,188 & 0,036 & 0,044 & 0,162 & 0,022 & 0,188 \\
\hline Turkland Bank A.Ş. & 0,000 & 0,001 & 0,000 & 0,007 & 0,016 & 0,002 \\
\hline Average & 0,100 & 0,021 & $\mathbf{0 , 0 1 7}$ & 0,032 & 0,009 & 0,045 \\
\hline Bank & 2008 & 2009 & 2010 & 2011 & 2012 & Average \\
\hline T.C. Ziraat Bankası A.Ș. & 0,001 & 0,000 & 0,000 & 0,000 & 0,000 & 0,002 \\
\hline Türkiye Halk Bankası A.Ş. & 0,000 & 0,000 & 0,000 & 0,000 & 0,000 & 0,000 \\
\hline T. Vakıflar Bankası T.A.O. & 0,000 & 0,000 & 0,000 & 0,000 & 0,000 & 0,001 \\
\hline Adabank A.Ș. & 0,000 & 0,000 & 0,000 & 0,000 & 0,000 & 0,000 \\
\hline Akbank T.A.Ş. & 0,001 & 0,000 & 0,004 & 0,000 & 0,000 & 0,001 \\
\hline Alternatif Bank A.Ș. & 0,000 & 0,000 & 0,000 & 0,000 & 0,000 & 0,000 \\
\hline Anadolubank A.Ş. & 0,000 & 0,000 & 0,000 & 0,000 & 0,000 & 0,001 \\
\hline Şekerbank T.A.Ş. & 0,000 & 0,000 & 0,000 & 0,001 & 0,000 & 0,000 \\
\hline Tekstil Bankası A.Ş. & 0,000 & 0,000 & 0,000 & 0,000 & 0,000 & 0,000 \\
\hline Turkish Bank A.Ș. & 0,000 & 0,005 & 0,002 & 0,018 & 0,004 & 0,025 \\
\hline Türk Ekonomi Bankası A.Ş. & 0,014 & 0,000 & 0,001 & 0,003 & 0,000 & 0,005 \\
\hline Türkiye Garanti Bankası A.Ş. & 0,001 & 0,000 & 0,000 & 0,000 & 0,000 & 0,000 \\
\hline Türkiye İş Bankası A.Ş. & 0,000 & 0,002 & 0,000 & 0,000 & 0,000 & 0,013 \\
\hline Yapı ve Kredi Bankası A.Ş. & 0,003 & 0,000 & 0,000 & 0,000 & 0,000 & 0,046 \\
\hline Arap Türk Bankası A.Ş. & 0,000 & 0,015 & 0,006 & 0,000 & 0,001 & 0,060 \\
\hline Citibank A.Ş. & 0,009 & 0,009 & 0,037 & 0,016 & 0,023 & 0,016 \\
\hline Denizbank A.Ş. & 0,000 & 0,000 & 0,000 & 0,000 & 0,000 & 0,001 \\
\hline Deutsche Bank A.Ş. & 0,001 & 0,033 & 0,060 & 0,000 & 0,032 & 0,024 \\
\hline Burgan Bank A.Ş. $^{+}$ & 0,257 & 0,001 & 0,174 & 0,034 & 0,000 & 0,112 \\
\hline Finans Bank A.Ş. & 0,000 & 0,001 & 0,000 & 0,000 & 0,000 & 0,002 \\
\hline Fortis Bank A.Ş. & 0,001 & 0,000 & NA & NA & NA & 0,003 \\
\hline HSBC Bank A.Ş. & 0,000 & 0,001 & 0,027 & 0,007 & 0,001 & 0,005 \\
\hline ING Bank A.Ș. & 0,001 & 0,000 & 0,000 & 0,000 & 0,000 & 0,005 \\
\hline Fiba Bank A.Ş. ${ }^{++}$ & 0,035 & 0,026 & 0,078 & 0,000 & 0,000 & 0,064 \\
\hline Turkland Bank A.Ş. & 0,006 & 0,000 & 0,000 & 0,006 & 0,000 & 0,005 \\
\hline Odeobank $^{+++}$ & $\mathrm{NA}$ & NA & NA & NA & 0,270 & 0,270 \\
\hline Average & 0,013 & 0,004 & 0,016 & 0,004 & 0,003 & 0,025 \\
\hline
\end{tabular}

Table 4. Predicted failure probabilities for 2002-2012 
Figure 1 below based on the Tables 3 and 4, illustrates this sharp decline in the average probability of failures predicted by the ANN models. Economic and financial measures that were undertaken after 2001 crisis, which in part were designed to better scrutinize the financial system and specifically banks, seem to be paying off. Despite the deterioration of macroeconomic conditions in Turkey, in term of growth, unemployment, inflation, difficulties in the export markets, a global financial crisis shaking the World, and a relatively unstable political environment in recent years, the Turkish commercial banks appear to be quite far from the risk of failure.

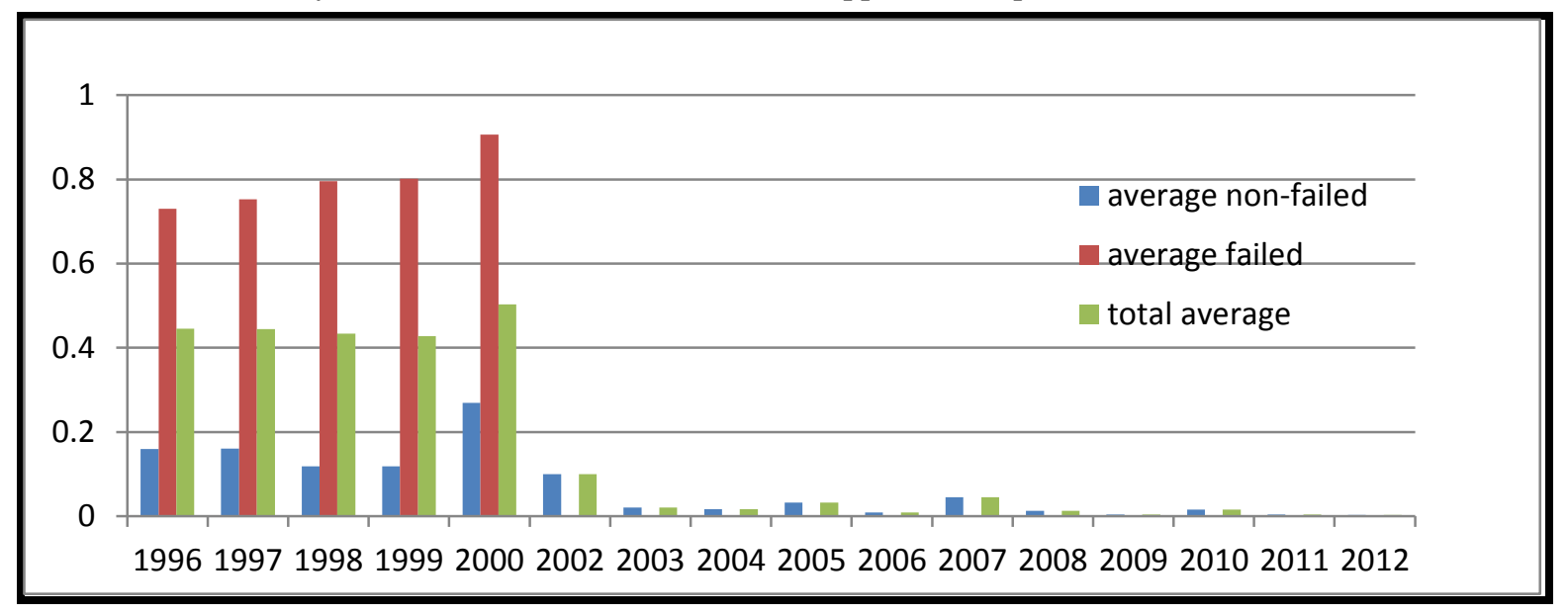

Figure 1. Average probabilities of failures by years

\section{Concluding Remarks}

Economic conditions also appear to affect the probability of bank failures. Banking crises happen when the macroeconomic environment is weak, particularly when growth is low and inflation is high. In addition, high real interest rates are in general associated with systemic problems of the banking sector (Demirgüç-Kunt and Detragiache, 1998). The moral hazard problem (financial liberalization combined with explicit deposit insurance and weak law enforcement) also increase the failure probabilities (Hutchison and McDill, 1999).

All of the above macroeconomic problems were observed in Turkey during the period of 1992-2013 to various degrees, contributing to the failure of 26 banks between 1994 and 2003. There is no doubt that the adverse macroeconomic conditions contributed to the bank failures in Turkey. However, no banks failed in Turkey after 2003, despite the global financial crises and the failures experienced by some of the prominent players of the global financial system. It can be argued that the adverse macroeconomic conditions and the unfavorable global financial environment have increased the probability of bank failures. Nevertheless, the non-failed banks in Turkey have survived in contrast to the group that failed under the same adverse macroeconomic conditions and financial environment. Hence, this study underlines two important factors unequivocally contributing to bank failures: 1) internal conditions resulting from a bank's own mismanagement and misguided policies; and 2) the failure of monitoring agencies to warn the banks and to take under close examination of those with high potential to fail. Measures that were undertaken after 2001 crisis to better scrutinize the financial system and banks, seem to be paying off.

After the 2001 crisis, Turkey started to apply a transition program toward to the stronger economy in February 2001. Within this program, restructuring of Turkish banking sector had been started and applied in the period of 2002-2007. Important changes and arrangements were made in the banking laws and regulations in order to harmonize with the international standards and applications. So, banking regulation and supervising agency became more effective in monitoring and supervising of banks. Results of this study strongly support the positive effects of these regulations on Turkish banking sector after 2001 (Figure 1). Hence, if decision makers monitor banks over time, they can capture a significant amount of information about the changes in financial condition of banks. Using financial ratios that have significantly different means for failed and non-failed group of banks provides more refined and enhanced information to decision makers than using all financial ratios directly. As such, they can become part of the early warning toolkit available to internal management and bank supervising agencies.

A cursory examination of recent bank failures in the United States suggests that similar factors may have played a role in the wave of fresh bank failures. Future research can further scrutinize whether these findings hold true for other countries. 


\section{References}

- Alam, P., Booth, L.K. and Thordarson, T., 2000. "The Use of Fuzzy Clustering Algorithm and SelfOrganizing Neural Networks for Identifying Potentially Failing Banks: an Experimental Study", Expert Systems with Applications, 18, 185-199.

- Arena, M., 2008. "Bank Failures and Bank Fundamentals: A Comparative Analysis of Latin America and East Asia During the Nineties Using Bank-Level Data", Journal of Banking \& Finance, 32(2), 299-310.

- Banking Regulation and Supervision Agency (BRSA), 2003. Banking Sector Restructuring Program: Progress Report, 23, October, 2003.

- Boyacioglu, M. A., Kara, Y. and Baykan, Ö.K., 2009. "Predicting Bank Financial Failures Using Neural Networks, Support Vector Machines and Multivariate Statistical Methods: A Comparative Analysis in the Sample of Savings Deposit Insurance Fund (SDIF) Transferred Banks in Turkey”, Expert Systems with Applications, 36(2), 3355-3366.

- Brown, C.O., Dinç, I. S., 2011. "Too Many to Fail? Evidence of Regulatory Forbearance When the Banking Sector is Weak", Review of Financial Studies, 24(4), 1378-1405.

- Canbaş, S., Çabuk, A. and Kılıç, S.B., 2005. "Prediction of Commercial Bank Failure via Multivariate Statistical Analysis of Financial Structures: The Turkish case", European Journal of Operational Research, 166 (2), 528-546.

- Cebula, R., Koch, J and Fenili R., 2011. “The Bank Failure Rate, Economic Conditions and Banking Statutes in the U.S., 1970-2009”, Atlantic Economic Journal, 39(1), 39-46.

- Chauhan, N., Ravi, V., Karthik Chandra, D., 2009. "Differential Evolution Trained Wavelet Neural Networks: Application to Bankruptcy Prediction in Banks", Expert Systems with Applications, 36(4), 76597665.

- Cole, R., A. and Gunther, J.W., 1998. "Predicting Bank Failures: A comparison of On-and Off-Site Monitoring Systems", Journal of Financial Services Research, 13(2), 103-117.

- Cole, R., White, L., 2102. "Déjà Vu All Over Again: The Causes of U.S. Commercial Bank Failures This Time Around", Journal of Financial Services Research, 42(1/2), 5-29.

- Demirgüç-Kunt, A. and Detragiache, E., 1998. "The Determinants of Banking Crises in Developing and Developed Countries”, IMF Staff Papers 45 (1).

- Erdal, H., Ekinci, A., 2013. "A Comparison of Various Artificial Intelligence Methods in the Prediction of Bank Failures”, Computational Economics, 42(2), 199-215.

- Fatima, A., Silvia R. (2013) "Characteristics of Failed U.S. Commercial Banks: an Exploratory Study", Accounting \& Finance, 53(4), 1149-1174.

- Fungáčová, Z., Weill, L., 2013. "Does Competition Influence Bank Failures? Evidence from Russia", Economics of Transition, 21(2), 301-322.

- Huang, D-T., Chang, B. and Liu, Z-C., 2012. "Bank Failure Prediction Models: for the Developing and Developed Countries", Quality \& Quantity, 46(2), 553-558.

- Hutchison, M. and McDill, K., 1999. "Are All Banking Crises Alike? The Japanese Experience in International Comparison”, NBER Working Paper 7253.

- Jin, J.Y., Kanagaretnam, K. and Lobo, G.J., 2011. "Ability of Accounting and Audit Quality Variables to Predict Bank Failure During the Financial Crisis”, Journal of Banking \& Finance, 35(11), 2811-2819.

- Jin, J.Y., Kanagaretnam, K., Lobo, G. and Mathieu, R., 2013. "Impact of FDICIA Internal Controls on Bank Risk Taking", Journal of Banking \& Finance, 37( 2), 614-624.

- Jo, H. and Han, I., 1996. "Integration of Case-Based Forecasting, Neural Network and Discriminant Analysis for Bankruptcy Prediction", Expert Systems with Applications, 11, 415-422.

- Kılıç, S.B., 2003. "Mali Başarısızlık Tahmininde Çok Değişkenli Istatistiksel Yöntemlerin ve Çok Kriterli Analize Dayali Bir Modelin Kullanılması: Türk Bankacılık Sisteminde Bir Uygulama (Using Multivariate Statistical Methods and a Model of Multicriteria Analysis in Predicting Financial Failure: An Application in the Turkish Banking Sector)", Unpublished Ph.D. Thesis, Çukurova University, Institute of Social Sciences, Adana, Turkey.

- Kolari, J., Glennon, D., Shin, H. and Caputo, M., 2002. "Predicting Large US Commercial Bank Failures", Journal of Economics \& Business, 54, 361-387.

- Lam, K.F. and Moy, J.W., 2002. "Combining Discriminant Methods in Solving Classification Problems in Two-Group Discriminant Analysis", European Journal of Operational Research, 138, 294-301. 
- $\quad$ Lopcu, K. and Kılıç, S.B., 2012. "Effects of Structural Changes in the Turkish Banking Sector Since 2001 Crisis and a Risk Analysis for the Sector". Topics in Middle Eastern and North African Economies, Electronic Journal, 14, Middle East Economic Association and Loyola University Chicago, September,

- $\quad$ Meyer, P.A. and Piffer, H.W., 1970. "Prediction of Bank Failures”, Journal of Finance, 25, 853-868.

- Pantolone, C. and Platt, M.B., 1987. "Predicting Commercial Bank Failure Since Deregulation”, New England Economic Review, 37-47.

- $\quad$ Penas, M., Tümer-Alkan, G., 2010. "Bank Disclosure and Market Assessment of Financial Fragility: Evidence from Turkish Banks’ Equity Prices”, Journal of Financial Services Research, 37(2/3), 159-178.

- Revaluation index, 2014. İstanbul vergi dairesi başkanlığ1, http://www.ivdb.gov.tr/pratik/oranlar/kirk.htm

- Rose, P.S. and Kolari, J.W., 1985. "Early Warning Systems as a Monitoring Device for Bank Conditions", Quarterly Journal of Business and Economics, 24(1), 43-60.

- $\quad$ Shin, S.W. and Kılıç, S.B., 2006. "Using PCA-Based Neural Network Committee Model for Early Warning of Bank Failure", Lecture Notes in Computer Science Book Series; Advances in Natural Computation 4221/2006, 289-292.

- $\quad$ Shin, S.W., Lee, K.C. and Kılıç, S.B., 2006. "Ensemble Prediction of Commercial Bank Failure Through Diversification of Input Features", Lecture Notes in Computer Science Book Series; Advances in Artificial Intelligence 4304/2006, 887-896.

- Sinkey, J., 1975. "A Multivariate Statistical Analysis of the Characteristics of Problem Banks", Journal of Finance, 30(1), 21-38.

- $\quad$ Tam, K.Y. and Kiang, M.Y., 1992. "Managerial Applications of Neural Networks: The Case of Bank Failure Predictions", Management Science, 38(7), 926-947.

- Zhao, H., Sinha, A. P. and Ge, W., 2009, "Effects of Feature Construction on Classification Performance: An Empirical Study in Bank Failure Prediction”, Expert Systems with Applications, 36( 2), 2633. 